\title{
THE EFFECT OF MOVEMENT TRAINING ON BALANCE SKILLS IN CHILDREN WITH INTELLECTUAL DISABILITY ${ }^{i}$
}

\author{
Faruk Salih Şeker ${ }^{1 i i}$, \\ Hüseyin Çamlıyer ${ }^{2}$ \\ 'Physical Education and Sport Sciences, \\ İstanbul Gedik University, \\ İstanbul, Turkey \\ 2Physical Education and Sport Sciences, \\ Manisa Celal Bayar University, \\ Manisa, Turkey
}

\begin{abstract}
:
Our study tried to assess the effect of the Special Movement Education Program on the balance skills of children with intellectual disabilities. We used the experimental design of 23 children with intellectual disabilities between the ages of seven and ten in a special education and rehabilitation center in Burdur, Turkey formed the study group. We applied the Basic Movement Training Program designed to develop balance skills to the experimental group. We practiced 22 courses of 45 minutes two days a week for 11 weeks before and after the application. The study continued for 13 weeks. We used Sensory Profile Test, Pediatric Balance Scale, Flamingo Balance Test, Balance Test on Walking Device, Standing Test on Balance Device, and Balance Measurement Device data collection tools. Mann Whitney U Test and Wilcoxon Test, which are non-parametric tests, were used in this study. We found a significant difference between the pre-test and post-test scores of the experimental group. The finding results revealed that children with intellectual disabilities improved their balance skills with movement training.
\end{abstract}

Keywords: intellectual disability, movement training, balance skill, sensory profile, sensory integration

\section{Introduction}

Between 10 and 55\% of children have problems with the processing and organization of sensory information. Studies show that sensory integration problem rate can go up to 40$88 \%$ for children with different diagnoses (Vakulenko, 2020). A. Jean Ayers introduced the term sensory integration firstly in 1972. The term refers to a field in individuals,

${ }^{\mathrm{i}}$ This article was re-produced in unpublished doctoral thesis number 576675 entitled The Effect of Movement Training on Balance Skills in Children with Intellectual Disability.

ii Correspondence: email salih seker@hotmail.com 
particularly children, who exhibit atypical behavioral responses to sensory stimulation. Sensory integration has established a theoretical framework for diagnosing and treating disabilities in children under sensory integration disorder (SID) for the past fifty years. More recently, the approach has been reshaped as "dimensions of sensory processing" or SPD rather than SID (Camarata et al., 2020).

Intellectual disability refers to in many countries as "mental deficiency" or "mental disability". However, the appearance of intellectually disabled individuals is not different in many people. It is necessary to know the specific characteristics and related conditions of these individuals who have some problems that require attention. Some of such problems are epilepsy, hyperactivity, cerebral palsy, sensory impairment, and autism. The reasons for the maladaptive behaviors of children with intellectual disabilities are not only related to the cognitive status of these children. At the same time, the difficulties experienced by these individuals while trying to fulfill their other skills may cause maladaptive behaviors. However, in general, the brain damage that affects the intellectual levels of these individuals, other functions such as motor and sensory functions derived from brain processing can also cause maladaptive behaviors. Research shows that depending on the rate of intellectual disability, the motor skills of individuals may also be destroyed (Kosma et al., 2004; Ulla et al., 2007; World Health Organization [WHO], 2007; Engel-Yeger, 2011).

Children with intellectual disabilities may experience limitations in activities of daily living and a lack of self-confidence. However, they may lose their self-esteem, and they may also experience deficiencies in their academic skills. As children's disability levels increase, so does neurological damage. In addition, children's motor skills have a minimal effect on their sensory processing ability. However, the psychomotor activities revealed by movement training, doing, living, thinking, and practicing in these children increase the child's sensory information. Movement training can be available in curing the deficiencies that can be caused by the lack of sensory integrity (Alper and Ryndak, 1992; Engel -Yeger et al., 2011; Vuijk et al., 2010).

The movement training includes different combinations of psychomotor activities. For this reason, such events offer children a more enjoyable life. In other words, movement education facilitates children's education depending on their ability to focus better and react in a coordinated manner to different and rich stimuli (Wilson et al., 2011). This research considers that the "Basic Movement Education Program" supports "For Developing Balance Skills" for children with intellectual disabilities. Recent studies show the effects of movement programs on the advancement of balance skills in children with intellectual disabilities. The development of balance skills helps children with sensory integration disorders to adapt to social life, practice daily life activities, improve their self-confidence and self-esteem, and increase their academic skills. 


\section{Material and Methods}

Our study was to determine the effect of the movement education problem for developing balance skills on children with intellectual disabilities.

Random pretest-post-test control group design is the most preferred design among the true experimental designs. For this reason, we designed the research as a "random pre-test-post-test control group design", which is one of the types (Gürbüz \& Şahin, 2017).

The research proceeded for 13 weeks. It consisted of 23 children, and 11 children were in the control group and 12 in the experimental group. In the first week of the study, a pre-test was conducted on the children. In addition to the education in the curriculum for the children in the 11-week experimental group, we implemented the Basic Movement Training Program for two hours a week to improve the balance skills of the children. At the same time, the children in the control group continued their education in the rehabilitation center. At the end of the Basic Movement Training Program was employed to improve balance skills in the 13th week, we applied the post-test to the control and practice groups.

Table 1: Exercises with the Experimental Group and Their Duration

\begin{tabular}{|c|c|c|c|c|c|c|c|c|c|c|c|}
\hline Activities by Week & 1. & 2. & 3. & 4. & 5. & 6. & 7. & 8. & 9. & 10. & 11. \\
\hline 1. Exercises on the mat & $X$ & $X$ & $X$ & $X$ & & & & $X$ & & $X$ & $X$ \\
\hline 2. Rope movements & & $X$ & $X$ & & & & $X$ & & $X$ & & $X$ \\
\hline 3. Movements in balance equipment & & & & $X$ & & & $X$ & & $X$ & $x$ & $X$ \\
\hline 4. Movements in the ground balance equipment & & & & & $X$ & & $X$ & & & $X$ & $X$ \\
\hline 5. Paired movements & & & & & & & $X$ & $X$ & & $X$ & $X$ \\
\hline 6. Rhythm and coordination movements & & & & & & & & $X$ & $X$ & $X$ & $X$ \\
\hline
\end{tabular}

Table 1 shows the activities and durations applied in the study. We administered the post-test, which we had applied to the students in the experiment group and control group at the beginning of the movement program, again at the end of 11 weeks.

The sample of this study consisted of children with mild intellectual disabilities between the ages of seven and ten who were educated in a special education and rehabilitation center.

Twenty three students attending the rehabilitation center participated in the study. There were 11 students in the control group and 12 students in the experimental group in the study. Children with a report of mild intellectual disability participated in the study.

\subsection{Data Collecting Tools}

In the study, we used six different measurement tools for the children to collect data on the balance skills of children with intellectual disabilities. We employed these tools to the children in both groups as both a pre-test and a post-test. 
We took the opinion of three experts when choosing balance skills. We paid attention to the fact that the tools are applications that children can use in their daily lives and in games. In addition, we selected easy-to-get tools and materials suitable for the learning and implementation of the applications. We escalated the difficulty of the different variations of the movements we chose in the later stages of the study. We also ensured in-group participation with paired movements.

We received opinions from the language expert, the physical education and sports education specialist, and the measurement and evaluation experts in education regarding the questionnaire and scale. We made corrections in the questionnaires and scales according to expert opinions. Thus, we ensured the content validity and face validity of the measurement tools. Data collecting tools are listed following.

\subsubsection{Sensory Profile Test}

Winn Dunn developed the Sensory Profile Test. This test was implemented into measuring the sensory profile of children between the ages of three and 10 with intellectual disabilities, in programming and planning (Dunn \& Westman, 1997). Adaptation of this tool to Turkish language and culture was made by Kayıhan et al. (2015), and this test's validity and reliability were verified. The Cronbach Alpha internal consistency reliability of this scale was very high $(\alpha>$.90) (Kayıhan et al., 2015). The children's parents attain the test forms. It is scored in a five-point Likert system, and the variables consist of three parts. These are sensory processing, sensory modulation, behavioral and sensory responses. The sensory system includes auditory, visual, vestibular, tactile, multisensory, and gustatory regions. The information obtained with the sensory profile gives an idea about the child's ability to define sensory problems, interpret the senses, respond to and adapt to sensory stimuli from the environment, and his reactions to daily life activities (Dunn, 1999; Geyser, 2009).

In the study, we used only the scores of the "vestibular processing" sub-dimension, which was under the sensory processing dimension of the test, to correlate with balance. Sensory profile scoring of the vestibular process, Definite Difference $(11-44)$, Possible Difference (45 - 47), Typical Performance (48 - 55) (Aki et al., 2016). We received opinions from three different experts for the validity of the questionnaire, and we provided a common consensus in line with their thoughts.

\subsubsection{Pediatric Balance Scale}

The Pediatric Balance Scale is a modified version of the Berg Balance Scale. This balance scale was a balance measure for school-aged children aged five to 15 years with mild or moderate motor impairment. The Pediatric Balance Scale is used to evaluate the functional balance of children in activities of daily living. Researchers have been using it in clinical studies, researches, and theses in Turkey for years. In the study, the researchers asked participants to perform 14 different movements. For each activity, zero was low, and four was the best score. The maximum score of the test was 56. The closer the score 
was to 56, the better the child's balance was considered. Total test administration and scoring time were 15 minutes (Franjoine et al., 2003).

Three different experts gave their opinions on the validity of the scale in the study. As a result of these opinions, we reached a consensus.

\subsubsection{Balance Measurement Tool}

We obtained the data of mediolateral deviation with eyes open, mediolateral deviation with eyes closed, anterior-posterior deviation with eyes open, and anterior-posterior deviation with eyes closed. Mediolateral velocity with eyes open, mediolateral velocity with closed eyes, anterior-posterior velocity with eyes open, anterior-posterior velocity with closed eyes, distance with opened eyes, distance with eyes closed, static balance scores of eyes open and eyes closed. We used the ALFA AC International East Balance Meter to obtain these scores. We made the static balance measurements and evaluations with ALFA AC International East (P.H.U. Technomex, Poland) stabilometry device. We transferred the data obtained to the computer with special software.

In this study, we provided the same measurement conditions for the control and experimental groups. The assessment protocol was for each participant in a standing position on the platform. We made each successive measurement at the same location. After the participant got on the balance beam and stabilized, we started the Romberg Test. In the test, we made the measurements with eyes open for 30 seconds and eyes closed for 30 seconds. We repeated the experiments if the participants got off the balance beam or moved before the test was over. We obtained static balance scores as a pretest and posttest after these measurements before starting the movement training (Henriksson et al., 1967).

\subsubsection{Flamingo Balance Test}

Flamingo Balance Test is a general body test. In the test, we used a balance beam, its length was $50 \mathrm{~cm}$ and height was four $\mathrm{cm}$, and width was three $\mathrm{cm}$. While balancing on one leg, preferred leg, the child flexed free leg at the knee and kept the foot of this leg close to the hip started the time the child tried to balance for a minute. We measured how many times the child's foot touched the ground while in this position. We stopped the timer when the child's balance was interrupted. When the child regained his balance by climbing on the balance beam, we started the chronometer from where he left off. The test went on like this for one minute. When the one-minute test period was complete, we counted each attempt of the child to balance (after falling) and recorded this number as the child's score. We did not evaluate the test when the child lost more than 15 balances (Rodriguez et al., 1998; Adam et al., 1987).

\subsubsection{Balance Test on Walking Device}

Measuring balance skills of the children with intellectually disabled this balancing test, we used a $180 \mathrm{~cm}$ long, seven $\mathrm{cm}$ high, and five $\mathrm{cm}$ wide board. We measured the walking times of the children on the board with a digital stopwatch. We repeated the test when 
the children lost their balance (if they fell off the board or their feet touched the ground). We recorded the time between the starting point on the board and the ending point as the child's score.

\subsubsection{Standing on the Balance Board Test}

To measure the balance tests for intellectually disabled children, we used a board eight $\mathrm{cm}$ high and $55 \mathrm{~cm}$ in width. We measured how long the children could balance with both feet on this tool. We repeated the test when the children lost their balance (if they fell off the board, their feet touched the ground or touched something with their hands). We measured the time duration between the children starting to balance and losing their balance with a digital chronometer, and as a result, we accepted this time as the child's score.

\subsection{Analyzing Data}

In the research, we analyzed the frequency and percentage distributions and the demographic characteristics of the experimental and control groups.

We used the Shapiro-Wilk Test to test whether the data were statistically suitable for normal distribution. Because the sample number was below 30. Significance values were less than 0.05 as a result of Shapiro-Wilk test. The data did not show a normal distribution. As Gürbüz and Şahin (2017) stated, non-parametric tests should be applied to test hypotheses in cases where the data do not show normal distributing. We used the Shapiro-Wilk Test to test whether the data were statistically suitable for normal distribution.

We used the Mann-Whitney U non-parametric test in our study. It examined the hypothesis and compared the control group and the experimental group. We analyzed the difference between the pre-test and post-test of the control and experimental group. We assessed the difference between the pre-test and post-test data of the experimental group and the pre-test data and post-test data of the control group with the Wilcoxon test, which is one of the non-parametric tests.

\section{Research Findings}

\subsection{Mann Whitney U Test for the Pre-Test and the Post-Test Comparisons between Groups}

The research findings stated that there was no significant difference between the pre-test scores of the groups according to the Sensory Profile Vestibular Process Scoring. However, there was a meaningful difference between the post-test scores of the control and experimental groups. In addition, while there was no significant difference between the pre-test and post-test scores of the control group in Sensory Profile Vestibular Process Scoring, there was a meaningful difference between the pre-test and post-test scores of the experiment group. 


\subsection{Wilcoxon Test for Comparison of Pre-Test and Post-Test Between Groups}

Wilcoxon test showed that there was a significant difference between the pre-test and post-test of the experimental group. In addition, there was no significant difference between the pre-test and post-test in the control group. The tests in which there was no difference sensory profile test vestibular process, pediatric balance scale, balance test on walking apparatus, standing test on balance apparatus, flamingo balance test, eyes open mediolateral mean deviation, eyes closed mediolateral mean deviation, eyes open mediolateral mean velocity, eyes closed mediolateral mean velocity, eyes open anteriorposterior mean, eyes closed anterior-posterior mean velocity, eyes open distance $(\mathrm{cm})$ data, and eyes closed distance $(\mathrm{cm})$.

Table 2: Eyes Open Anterior-Posterior Mean Deviation Results

\begin{tabular}{|c|c|c|c|c|c|c|}
\hline & & $\mathbf{n}$ & $\bar{x}$ & ss & $\mathrm{Z}$ & $\mathbf{P}$ \\
\hline \multirow[t]{2}{*}{ Experimental group } & Pre-test & 12 & 14,51 & 1,775 & \multirow{2}{*}{$-0,353$} & \multirow{2}{*}{0,724} \\
\hline & Post-test & 12 & 14,33 & 2,632 & & \\
\hline \multirow[t]{2}{*}{ Control group } & Pre-test & 11 & 14,41 & 1,153 & \multirow{2}{*}{$-2,090$} & \multirow{2}{*}{0,037} \\
\hline & Post-test & 11 & 15,96 & 1,640 & & \\
\hline
\end{tabular}

$\mathrm{p}<0.05$

Table 2 presents the Eyes Open Anterior-Posterior Mean Deviation Results. As stated in the test results of the experimental group performed before the movement training program, the mean of the Eyes Open Anterior-Posterior deviation results was 14.51, and the standard deviation was 1.77. After attending the movement training program, the mean of the post-test results was 14.33, and the standard deviation was 2.63. The research findings showed that the difference between the Eyes Open Anterior-Posterior Mean Deviation results before and after participating in movement training $p<0.05$ was not significant $(Z=-0.353 ; p=0.724)$.

The research findings indicate that the pre-test mean of the Eyes Open AnteriorPosterior deviation results of the control group was 14.4, and the standard deviation was 1.15. However, the findings revealed that the mean of the control group post-test results was 15.96, and the standard deviation was 1.64. The findings demonstrated that the difference between the pre-test and post-test results was significant at $p<0.05(Z=-2.090$; $\mathrm{p}=0.037)$.

Table 3: Anterior - Posterior Mean Deviation Results with Eyes Closed

\begin{tabular}{|l|l|c|c|c|c|c|}
\hline & & $\mathbf{n}$ & $\mathbf{X}$ & $\mathbf{s s}$ & $\mathbf{Z}$ & $\mathbf{P}$ \\
\hline \multirow{2}{*}{ Experimental group } & Pre-test & 12 & 14,45 & 1,598 & \multirow{2}{*}{$-1,245$} & \multirow{2}{*}{0,213} \\
\cline { 2 - 6 } & Post-test & 12 & 13,24 & 1,524 & & \multirow{2}{*}{0,091} \\
\hline \multirow{2}{*}{ Control group } & Pre-test & 11 & 14,45 & 1,488 & \multirow{2}{*}{$-1,689$} & \multirow{2}{*}{} \\
\cline { 2 - 5 } & Post-test & 11 & 15,71 & 1,680 & & \\
\hline
\end{tabular}

$\mathrm{p}<0.05$

Before attending the movement training program of the experiment group, the Eyes Closed Anterior-Posterior deviation finding was 14.45, and the standard deviation was 
1.59. After attending the movement training program, the post-test results show that the mean was 13.24, and the standard deviation was 1.52. The findings confirmed that the difference between the Eyes Closed Anterior-Posterior Mean Deviation test results before and after was not meaningful at the $\mathrm{p}<0.05$ significance ratio $(Z=-1.245 ; \mathrm{p}=0.213)$.

As seen in Table 3, the pre-test mean of the Eyes Closed Anterior-Posterior Mean Deviation test results for the control group was 14.45, and the standard deviation was 1.48. The control group post-test results expressed the mean was 15.71, and the standard deviation was 1.689. The test results displayed that the difference between the pre-test and post-test results was not meaningful at $p<0.05$ significance $(Z=-1.689 ; p=0.091)$.

Table 4: Eye Open Area $\left(\mathrm{cm}^{2}\right)$ Results

\begin{tabular}{|c|c|c|c|c|c|c|}
\hline & & $\mathbf{n}$ & $\bar{x}$ & ss & $\mathrm{Z}$ & $\mathbf{P}$ \\
\hline \multirow[t]{2}{*}{ Experimental group } & Pre-test & 12 & 6,75 & 4,541 & \multirow{2}{*}{$-1,806$} & \multirow{2}{*}{0,071} \\
\hline & Pro-test & 12 & 3,99 & 1,651 & & \\
\hline \multirow[t]{2}{*}{ Control group } & Pre-test & 11 & 8,79 & 10,134 & \multirow{2}{*}{$-2,934$} & \multirow{2}{*}{0,003} \\
\hline & Pro-test & 11 & 20,52 & 13,274 & & \\
\hline
\end{tabular}

$\mathrm{p}<0.05$

Before the children with intellectual disability participated in the movement training program, the mean of the Eyes Open Area $\left(\mathrm{cm}^{2}\right)$ results of the experiment group was 6.75, and the standard deviation was 4.54. After the children attended the movement training, the mean of the post-test results of these students was 3.99, and the standard deviation was 1.65. These findings presented that the difference between Eyes Open Field results before and after children's movement training was not noteworthy at $p<0.05(Z=-1.80$; $\mathrm{p}=0.071$ ).

The pre-test mean of the Eyes Open Area results of the control group was 8.79, and the standard deviation was 10.13. The post-test results of the control group showed that the mean was 20.52, and the standard deviation was 13.27. The results showed that the difference between the pre-test and post-test was significant at $p<0.05(Z=-2.93 ; p=0.003)$.

Table 5: Eyes Closed Area $\left(\mathrm{cm}^{2}\right)$ Results

\begin{tabular}{|c|c|c|c|c|c|c|}
\hline & & $\mathrm{n}$ & $\bar{x}$ & ss & $\mathrm{Z}$ & $\mathbf{P}$ \\
\hline \multirow[t]{2}{*}{ Experimental group } & Pre-test & 12 & 13,42 & 9,777 & \multirow{2}{*}{$-2,550$} & \multirow{2}{*}{0,011} \\
\hline & Pro-test & 12 & 5,31 & 3,857 & & \\
\hline \multirow[t]{2}{*}{ Control group } & Pre-test & 11 & 11,09 & 4,668 & \multirow{2}{*}{$-2,045$} & \multirow{2}{*}{0,041} \\
\hline & Pro-test & 11 & 23,80 & 15,01 & & \\
\hline
\end{tabular}

$\mathrm{p}<0.05$

The mean of the Eyes Closed Field $\left(\mathrm{cm}^{2}\right)$ test results before participating in the movement training program of the experimental group was 13.42, and the standard deviation was 9.77. After this group attended the movement training, the mean of the post-test result was 5.31, and the standard deviation was 3.85. These findings indicated that the difference between the Eyes Closed Field results before and after the training was significant at $\mathrm{p}<0.05$ significance rate $(\mathrm{Z}=-2.55 ; \mathrm{p}=0.011)$. 
The pre-test mean of the Eyes Closed Field result of the control group was 11.09, and the standard deviation was 4.66. The control group stated the post-test results, the mean of this test was 23.80, and the standard deviation was 15.01. As seen in Table 5, the findings showed that the difference between the pre-test and post-test results was $\mathrm{p}<0.05$ negatively significant $(\mathrm{Z}=-2.04 ; \mathrm{p}=0.041)$.

\section{Discussion}

Sensory integration disorders frequently happen in individuals with intellectual disability. This study aimed to investigate how the Basic Movement Training Program developed to improve balance skills contributes to an advancement in the vestibular sense. Our capability to uphold balance and body posture is provided by the vestibular sense. The study findings indicated the differences between the pre-test and post-test results of the experimental and control groups.

First, the Sensory Profile Vestibular Process Score showed no significant difference between the pre-test scores of the control and experimental groups. However, there were considerable differences between the groups' post-test scores. Secondly, Sensory Profile Vestibular Process Scoring stated that there was no significant difference between the pre-test and post-test scores of the control group. However, there was a meaningful difference between the pre-test and post-test scores of the experimental group. The research finding showed that the movement program impacted the development of the vestibular process. Akı et al. (2016) supported our research findings. Akı et al. (2016) conducted a study with four children aged between four and 11 years with an autism spectrum disorder in 14 sessions for seven weeks. The researchers examined pre-test and post-test the experimental group and the control group. Although the experimental group advanced the aquatic therapeutic activities treatment and received sensory integration therapy, the control group received only sensory integration therapy. They evaluated the vestibular processing portion of the Dunn Sensory Profile, Ayres' posture imitation, and bilateral motor coordination data. They stated that treatment of the therapeutic water activities increased the vestibular process, posture imitation, and bilateral motor coordination in children with autism. The Control group received only sensory integration therapy. They evaluated the vestibular processing portion of the Dunn Sensory Profile, Ayres' posture imitation, and bilateral motor coordination data. They stated that therapeutic water activities increased the vestibular process, posture imitation, and bilateral motor coordination in children with autism.

Dunn and Brown's (1997) study affirmed that the sensory profile lets strengthen the sensory processing skills that affect the child's performance. This research revealed that students with intellectual disabilities had positive developments in their sensory processing skills, depending on the improvement in their vestibular processing scores. Furthermore, Huri and Gündüz (2016) supported Dunn and Brown's studies. The researchers' study with the participation of gifted children between the ages of four and six stated that sensory integration therapy improved students' praxis, sensory-motor 
skills, and balance. They also stated that the development in the sensory integration skills of gifted students also contributed to their postural praxis and bilateral motor coordination skills. Huri and Gündüz's (2016) research revealed that experimental therapy practice could improve students' sensory-based group activities while improving students' social participation skills.

Pediatric Balance Scale findings revealed that while there was no significant difference between the pre-test scores of both groups, there was a meaningful difference between the post-test scores of the control and experimental groups. However, the Pediatric Balance Scale findings indicated that while there was no significant difference between the pretest-post-test scores of the control group, there was a substantial difference between the pre-test and post-test scores of the experimental group. These results showed that the scores of the students who participated in the training program were better than those who did not attend the program; the scores of the Pediatric Balance Scale were better. There was no significant difference between the pre-test and post-test scores of the control group, but there was a considerable difference between the pre-test and post-test scores of the experimental group. This finding obtained from the research supported the literature findings (Kubilay, 2008; Casey et al., 2015; Bingül, 2018). Kubilay (2008) examined the effectiveness of balance and posture exercises on functional levels in students with mild intellectual disabilities. Kubilay's (2008) study asserted was a statistically significant increase in the Pediatric Balance Scale scores of the control and experimental groups. Bingül (2018) used the Pediatric Balance Scale to compare two different groups. Bingül (2018) studied 41 unassisted ambulated spastic cerebral palsy and 41 healthy children (from four to 16 years). Bingöl's study determined functional balance using the Pediatric Balance Scale. It concluded that there was a difference in findings between the two groups.

The pre-test and post-test results of the experimental group proved that the movement training program caused improvements in the students with intellectual disabilities in the Sensory Profile Test Vestibular Process scores and Pediatric Balance Scale scores.

Even though there was no significant difference between the pre-test results of the groups based on the Balance Test scores on the Walking Device, there was a meaningful difference between the post-test results. There was no significant difference between the pre-test and post-test results of the control group. However, there was a meaningful difference between the pre-test-post-test results of the experimental group after the training program. While there was no significant difference between the pre-test and post-test scores of the control group, there was a substantial difference between the pretest and post-test scores of the experimental group. Odabaş (2016) stated that he investigated the effect of a 12-week exercise program on the motor competence levels of children with autism with 12 children aged between eight and 14 aged. In his research, he applied running speed, agility, balance, bilateral coordination, and strength tests from the parameters of the Bruininks-Oseretsky Motor Test to the children. The result of the study pointed that exercise training revealed a statistically significant difference in all 
tests. Odabaş's (2016) study supported our research findings. In another study, Demirel (2008) conducted eight weeks, 24 sessions with the experimental group to improve balance skills with a walking device. Demirel compared the students' first measurement and last measurement data. It revealed that balance education studies affected some selfcare skills of students. In addition, this study proved that these exercises had a positive effect on students' balance skills.

The findings obtained from the Balance Device Stand Test measurements revealed that while there was no significant difference between the pre-test scores of both groups, there was a significant difference between the post-test scores of the control and experimental group. The findings of the similar measurements showed that while there was no significant difference between the pretest-posttest scores of the control group, there was a significant difference between the pre-test-post-test scores of the experimental group that continued the movement program. Standing on Balance Equipment exercises are carried out in children with special learning difficulties, individuals with chronic low back disease, hearing-impaired, and the development of the balance of athletes. In addition, healthy and elderly individuals exercise for standing on the balance beam (Erbahceci et al., 2001; Coşkun and Filiz, 2012; Yağc1 et al., 2004; Akgül et al., 2018; Selçuk, 2018). The literature findings were consistent with the results of this study on balance skills in individuals with intellectual disability.

The Flamingo Balance Test findings showed that while the scores of both groups did not differ significantly between the pre-test findings of these groups, as in the other scores, there were significant differences between the groups' post-test scores. The result of the Flamingo Balance test displayed that while there was no significant difference between the pre-test and post-test results of the control group, there was a meaningful difference between the pre-test and post-test results of the experiment group. Many studies have been using the Flamingo Balance Test, for example, the balance performance measurements of athletes, the evaluation of motor fitness of pre-primary students, and the evaluation of balance control of old and young individuals (Hazar and Taşmdepligil, 2008; Fjørtoft 2000; Sundstrup et al., 2010; Atılgan Erkut et al., 2012; Erdogan et al., 2017). Erbahceci et al. (2001) used the balance board and the Flamingo Balance Test in balance training with 40 amputees. Erbahceci et al.'s (2001) study results argued that using a balance board was one of the effective procedures in balance training. The findings of our study and the literature findings were consistent. In a different research, Casey et al. (2015) put forward that children with autism spectrum disorder continuing their ice skating training for 12 weeks resulted in a significant increase in outcomes of these individuals' pediatric balance scale and Flamingo Balance Test. These researchers advocated the positive effects of ice skating training on the motor development of individuals with autism spectrum disorder. These findings were consistent with the results of our study.

After the experimental group participated in the movement training program, we subjected this group to the Walking Tool Balance Test, Standing on Balance Equipment 
Test, and Flamingo Balance Test. We achieved positive results in all tests. The test results supported the basic statement of the research.

The result of the Romberg Test statistical analysis performed with the Balance Measurement Device pointed that there was a significant difference in the pre-test and post-test results of the experimental and control groups, but only. However, the Field test of the control group with eyes closed showed that the test result was negative and significant.

The Romberg Test statistical analysis test performed with the Balance Measurement Device stated no significant difference between the pre-test and post-test results of the students in the blindfold Anterior-Posterior Mean Deviation control group. The groups were with open eyes Posterior Mean Deviation results showed a significant negative difference between the pre-test and post-test results of both groups. This result did not support our hypothesis. This finding of our study did not approve the results of Cheldavi et al. (2014). Cheldavi et al. (2014) also studied autistic children between the ages of six and eight on average (10 experiment group- 10 control group) for six weeks. Researchers applied a balance training program to improve the balance and postural control of these children. The researchers used the Bertec Mass Measuring Device, unlike our study. Measurements with this device exposed that children's eyes opened/closed, anterior-posterior results showed that movement programs effectively improved postural control in children. However, the results of our study suggested that, although there was no statistically significant difference in the experimental group, the frequencies of the test scores showed improvement and change. The frequencies of the control group indicated a decline. On the other hand, the study of Cheldavi et al. (2014) was consistent with our research according to the results of eyes open/closed, mediolateral, and average velocity. These results expressed that the Basic Movement Training Program Designed to Develop Balance Skills increased the balance skills of students with intellectual disability and improved their sense of balance.

Statistical analysis results of Romberg Test performed with Balance Meter in the control group presented that Eyes Open Anterior-Posterior Mean Deviation and Eyes Open Field were negatively different in the control group, but not in the experimental group. In other words, we can state that the scores of the students in the experimental group remained stable after the movement training, and there was a regression in the scores of the students in the control group. We can say that movement training did not improve the students of either group but tried to prevent the students from regressing. So, the movement program can be available as a preventive way to minimize regression in children with intellectual disabilities.

Our research findings showed that the Planned Basic Movement Training Program to Develop Balance Skills improved the balance skills of students with intellectual disabilities. These findings from our research were in agreement with the results of different studies (Dunn and Westman, 1997; Erbahceci et al., 2001; Fjørtoft, 2000; Yağc1 et al., 2004; Tomchek and Dunn, 2007; Hazar and Taşmdepligil, 2008; Sundstrup). 
et al., 2010; Atılgan Erkut et al., 2012; Coşkun and Filiz, 2012; Kapakkes, 2013; Erdoğan et al., 2017; Akgül et al., 2018; Selçuk, 2018).

The research findings stated a difference between the test results of the control group and the experimental group with the Balance Measurement Device according to the Basic Movement Training Program for 11 weeks. This finding was consistent with Mikołajczyk and Jankowicz-Szymańska's (2014) research, with only the difference between groups in the results of field measurements with eyes closed eyes, and no difference between groups in the anterior-posterior results with eyes open/closed. However, other findings of the study did not support our research results. Mikołajczyk and Jankowicz-Szymańska (2014) stated that there was no difference in the experiment group's test results regarding to the participants' eyes open mediolateral, anteriorposterior, distance, field and eyes closed, mediolateral, anterior-posterior, and distance. There may be several reasons why these findings differ from those of our study. For example, the study of Mikołajczyk and Jankowicz-Szymańska (2014) did not apply an appropriate movement training program to children with moderate intellectual disability. Various variables might affect the test results so as students' attention levels, psychological and social conditions, and external stimulus from the environment.

Today, Sensory Integration Therapy is widely applied to children with special education needs. In the literature, sensory integration studies are conducted in cerebral palsy and autistic children, elderly and physically disabled individuals in Turkey, and the world. However, there are not enough studies on the sense of balance of individuals with intellectual disabilities now.

Studies show that individuals with intellectual disabilities are developmentally behind compared to other individuals. For example, typically developing children start walking at an average age of one (Gündoğdu et al., 2016). Molnar's (1978) research revealed that children with Down's Syndrome started walking, on average, at the age of 4.2. The walking age of students with different intellectual disabilities was 3.2 (Molnar, 1978; Siedentop et al., 1986; Winnick \& Porretta, 2017; as cited in Özer et al. 1999). Another example is that children with intellectual disabilities perform poorly in the dynamic balance process compared to their peers. In addition, these children could not show the expected improvement in balance skill performance with increasing age (Rarick and Dobbins, 1972; as cited in Özer 2013). Beckung, and friends' studies (1997) on 88 intellectually disabled children with epilepsy showed that all these children had low motor and sensory development levels than other typically developing children. The age of motor development in children is generally low. Motor and sensory dysfunctions are common in these intellectually disabled children. Intellectually disable students often lack motivation. This situation worsens the immature motor behavior of these individuals. The age range in this study was between seven and ten years old. Movement training can increase the motivation of children. The most intense development of balance control occurs between the ages of seven and 12. The development skills of children are between the ages of nine and fourteen (Sterkowicz et al., 2012). The data in 
the literature and the results of our study show that besides movement education, the motivation and age of children may contribute to the development of balance skills.

Intellectually disable students have difficulties in adaptive behaviors, and these individuals have lower physical capacity and limited motor functions compared to their peers and other different sick individuals (Öztürk, 1995; Horvat \& Franklin, 2001; Smail \& Horvat, 2001). Due to developmental disadvantages, the education of students with intellectual disabilities is valuable. Clark and Clark (1978) discussed that the physical and motor development of mentally slow students was that these individuals did not play game enough and did not participate in movement training programs. The study stated that the students in the control group could not have the same improvement in their standard education as the students in the experimental group (Özer et al., 1999).

Developmental disadvantages in the physical and motor skills of students with intellectual disabilities also affect the development of these individuals in mental and affective areas. Physical growth, change in the length of the various parts of the body, change in skeletal size and condition, nervous - muscular system, function, and development of different organs are called physical growth. It significantly affects physical growth and development, motor performance, educational success, and social behavior (Bruininks, 1974; Gallahue and Ozmun, 1995; cited in Özer et al., 1999).

There are many studies on the effects of movement training on the development of educational achievement, daily life activities, visual perception, self-care skills, social development, social participation skills, and hyperactivity and attention deficit (Çamlıyer, 1994; Franjoine et al., 2003; Alp \& Çamlıyer, 2015; Huri and Gündüz, 2016; Bingül, 2018; Gür, 2018). Çamliyer (1994) stated that movement education had a considerable effect on the perceptual development of 53 students aged eight to fourteen at the level of trainable intelligence. In another study, Çalık et al. (2011) stated that in their study with 25 children with low vision, aged 11 years on average, visual perception and balance functions are important factors in the level of independence in activities of daily living. Kara et al. (2011) stated that balance training was essential in increasing gross motor function levels in children with Cerebral Palsy. On the other hand, they said that the changes in the psychomotor area were considered in the other field and that the improvement in balance skills increased the speed of learning self-care skills (Demirel, 2008). In another study, Alp (2014) stated that movement training and physical activities applied to autistic children supported the social development of students.

The movement training program strengthens the psychomotor activities of students with intellectual disabilities by doing, living, thinking, and practicing. In addition, movement training increases the child's sensory information, provides sensory integrity, and can alleviate students' inadequacies.

According to Karacan et al. (2003) stated that rhythm keeping skills, movement training, movement skills, movement and rhythm, movement variations, different rhythm exercises, children's ability to express themselves, the relationship between dance and health, the relationship between dance and science, paired studies, various movement exercises and educational programs that include educable intellectual work 
activities can contribute to improving the skills of individuals with intellectual disabilities.

Researchers thought that since movement education was based on psychomotor activities, such practices can be enjoyable and entertaining for students. Movement training strengthens the concentration of these individuals. This study is valuable in terms of being the first study on this subject in Turkey, revealing interdisciplinary findings, encouraging fundamental movement education for students with intellectual disabilities, and contributing to the literature.

\section{Recommendations}

Literature studies have shown that the intellectual disability of movement education contributes to students' educational success, daily life activities, self-confidence, visual perception development, self-care skills, social interactions, communication, and balance skills. In addition to these, applications such as movement and balance education, sensory integration therapy, active games, DIR Floor Time Model, Waldorf, Reggio Emilia, and Montessori Methods provide positive effects on these children's aggressive attitudes, hyperactivity, and attention deficits (Çamliyer, 1994; Edwards, 2002; Durgut et al., 2020; Gur, 2018). On the other hand, research by Jorquera-Cabrera et al. (2017) showed that there is only an English version of the Sensory and Integration Praxis Tests - SIPT, which was developed for children who are considered physically and intellectually normal but have special learning difficulties (Schaaf \& Miller, 2005). This test is suitable for the North American population approved for the North American population only. This situation limits the application of the test to other groups. In addition, the high cost of test training and testing is one of the limitations of this test (Jorquera-Cabrera et al., 2017). The results of our research and literature sources showed that it could produce similar results with the movement training program. Based on the results of this research, we suggest using movement training to avoid high costs and for more appropriate education.

Dunn and Brown's (1997) research stated that the sensory profile of children with intellectual disabilities could have sound potential to provide information about sensory processing skills that affect children's performance. It contains many behavioral elements rarely seen in disabled children. More scientific research is needed to identify appropriate practices for other groups of children.

The results of Bowman and Wallace's (1990) study with children aged 3-5 years show that the Developmental Test of Visual-Motor Integration (Beery, 1982), hand size and strength, Southern California Sensory Integration Tests (Ayres, 1972), Bowman Unilateral used by occupational therapists. Hopping Test (Flannigan, 1987), Southern California Postrotary Nystagmus Test (Ayres, 1975), Sensory Integration and Praxis Tests (SIPT) (Ayres, 1984), praxis tests, and Browman Quality of Prone Extension Scale (Etheredge, 1987) the test results differ according to the conditions. Researchers should keep this in mind when interpreting test results. 
Participation of intellectually disabled people in activities regularly leads to improvements in the skill levels of these individuals. The process of adapting to the activities is shorter for the disabled individuals in the inclusion group as against the other disabled group. The students in the mainstream group have a positive effect on each other. The social integration of children with average development with intellectually disabled children contributes positively to the personal development of their communication with their peers and their relations with disabling individuals. For this reason, making such activities widespread in line with the needs and wishes of students will contribute significantly to the development of students (Karacan et al., 2003).

Children who do not participate in the activities or are not taken part in by their friends have declines or loss of skills in physical and motor skills (Clark and Clark, 1978; Sinclaire and Forness, 1983; as cited in Özer et al., 1999). Similarly, Siedentop et al. (1986) affirmed that children with intellectual disabilities could improve their physical and motor skills through the games they participate. Therefore, we can say that students with intellectual disabilities should participate in more activities to adapt to other student groups.

\section{Conclusion}

The results of our research showed that the Special Movement Education Program on children with intellectual disabilities provided positive improvements not only in balance skills but also in educational success, daily living skills, visual perception, selfcare skills, social development, social participation, hyperactivity, and attention deficit. Education programs for individuals with intellectual disabilities should include intensive movement training exercises.

\section{Acknowledgments}

Both authors also contributed to the whole work. We wish to express our gratitude to the participants who volunteered for this study.

\section{Conflict of Interest Statement}

The authors declare that they have no conflict of interest related to the study or preparation of the manuscript.

\section{About the Authors}

Dr. Faruk Salih Şeker currently works at Istanbul Gedik University. His main current research interest lies in the area relationship between special education and sports.

Dr. Hüseyin Çamllyer is presently lecturing in the Faculty of Sport Sciences at Celal Bayar University. His research interests include special education, special teaching methods, and movement training material design. 


\section{References}

Adam C, Klissouras V, Ravazzolo M, Renson R, Tuxworth W, 1987. Eurofit: European test of physical fitness. Rome, Italy: Council of Europe, Committee for the Development of Sport

Akarsu R, Öztürk B, Kalkan E, 2018. Sosyal-bilişsel ve ince motor problemi olan bir çocukta ergoterapi müdahalesi: Bir olgu sunumu. Biruni Sağlık ve Eğitim Bilimleri Dergisi. Sayı: 1

Akgül A, Tarakci E, Arman N, Büyükkaya F, Irmak HS, Karaaslan T, 2018. Yaşlılarda denge, mobilite ve düşmenin değerlendirilmesi. Türkiye Klinikleri Tip Bilimleri Dergisi. 38 (1): 94-98

Akı E, Temuçin K, Aran OT, 2016. Su içi terapatik aktivitelerin vestibuler işlem, postür taklidi, bilateral motor koordinasyona etkisinin incelenmesi. Ergoterapi ve Rehabilitasyon Dergisi, 4 (2):103-113

Alp H, 2014. Correction of behavior problems in children with autism education and physical activity relationship of action. PhD Thesis, University of Manisa Celal Bayar

Alp H, Çamliyer H, 2015. The children participated with social adjustment disorders fused extracurricular movement education and game activities monitoring of children's social adaptation process next two years. International Journal of Social Sciences and Education Research, 1 (1): 109-120

Alper S, Ryndak DL, 1992. Educating students with severe handicaps in regular classes. The Elementary School Journal, 92 (3): 373-387

Atılgan Erkut AO, Akın M, Alpkaya U, Pınar S, 2012. Investigating of relationship between balance parameters and balance lost of elite gymnastics on balance beam. Journal of Human Sciences, 9 (2): 1260-1271

Ayres AJ, 1972. Sensory Integration and Learning Disorders. Western Psychological Services: Los Angeles

Beckung E, Steffenburg U, Uvebrant P, 1997. Motor and sensory dysfunctions in children with mental retardation and epilepsy. Seizure, 6 (1): 43-50

Beery KE, Buktenica NA, 1982. Administration, scoring, and teaching manual for the developmental test of visual-motor integration. Cleveland, $\mathrm{OH}$ : Modern Curriculum Press

Bingül DG, 2018. Assessment of pediatric balance scale and quantitative balance parameters in cerebral palsy. Thesis in Medicine, University of Marmara

Bowman OJ, Wallace BA. 1990. The effects of socioeconomic status on hand size and strength, vestibular function, visuomotor integration, and praxis in preschool children. American Journal of Occupational Therapy. 44 (7): 610-21

Bruininks RH, 1974. Physical and Motor Development of Retarded Persons, Ed: Ellis NR. International Review of Research in Mental Retardation, New York 
Camarata S, Miller LJ, Wallace MT, 2020. Evaluating Sensory Integration/Sensory Processing Treatment: Issues and Analysis. Front. Integr. Neurosci. 14:556660. doi: 10.3389/fnint.2020.556660

Casey AF, Quenneville-Himbeault G, Normore A, Davis H, Martell SG, 2015. A Therapeutic skating intervention for children with autism spectrum disorder. Pediatric Physical Therapy. 27 (2): 170-177

Cheldavi H, Shakerian S, Boshehri SNS, Zarghami M, 2014. The effects of balance training intervention on postural control of children with autism spectrum disorder: Role of sensory information. Research in Autism Spectrum Disorders. 8 (1): 8- 14

Clarke HH, Clark HD, 1978. Developmental and Adapted Physical Education. 2. edition. Prentice Hall Inc. Englewood Cliffs: New Jersey

Coşkun G, Filiz C, 2012. Kronik bel ağrısında dinamik ve statik stabilizasyon egzersizlerinin ağrı ve fonksiyonel düzeye etkileri. Fizyoterapi Rehabilitasyon. 23 (2): 65-72

Çalık BB, Yarar F, Cavla U, 2011. Az gören çocuklarda günlük yaşam aktiviteleri ile görsel alg1 ve denge fonksiyonları arasındaki ilişkinin incelenmesi. 2. Pediatrik Rehabilitasyon Kongresi Fizyoterapi Rehabilitasyon, 22 (3): 12

Çamlıyer H, 1994. Eğitilebilir zekâ düzeyindeki çocuklarda hareket eğitiminin algisal gelişim düzeylerine etkileri. PhD Thesis, University of Dokuz Eylül

Çöpkes $\ddot{U}, 2013$. Effect of vestibular rehabilitation in autistic children. Master Thesis, University of İstanbul Bilim

Dehghani M, Gunay M, 2015. The Effect of Balance Training on Static and Dynamic Balance in Children with Intellectual Disability, Journal of Applied Environmental and Biological Sciences, 5(9)127-131

Demirel N, 2008. Zihinsel engelli çocuklarda denge eğitimi çalişmalarinin bazi özbakim becerileri üzerine etkisinin incelenmesi. Master Thesis, University of Gazi

Dunn W, Brown C, 1997. Factor analysis on the sensory profile from a national sample of children without disabilities. The American Journal of Occupational Therapy. 51 (7): 490-495

Dunn W, 1999. Sensory Profile: User's manual. San Antonio, TX: The Psychological Corporation

Dunn W, Westman K, 1997. The Sensory Profile: The performance of a national sample of children without disabilities. The American Journal of Occupational Therapy. 51 (1): 25-34

Durgut E, Örengül, AC, Algun ZC, 2020. Comparison of the effects of treadmill and vibration training in children with attention deficit hyperactivity disorder: A randomized controlled trial. Neurorehabilitation, vol.47, no.2, 121-131

Edwards CP, 2002. Three approaches from Europe: Waldorf, Montessori, and Reggio Emilia. Early Childhood Research \& Practice. 4 (1)

Engel-Yeger B, Hardal - Nasser R, Gal E, 2011. Sensory processing dysfunctions as expressed among children with different severities of intellectual developmental disabilities. Research in Developmental Disabilities. 32 (5): 1770-1775 
Erbahceci F, Yigiter K, Sener G, Bayar K, Ulger O. 2001. Balance training in amputees: Comparison of the outcome of two rehabilitation approaches. Journal of Arthroplasty \& Arthroscopic. 12 (2): 184-88

Erdoğan CS, Fatmanur ER, İpekoğlu G, Çolakoğlu T, Zorba E, Çolakoğlu FF, 2017. Farklı denge egzersizlerinin voleybolcularda statik ve dinamik denge performansı üzerine etkileri. Spor ve Performans Araştırmaları Dergisi. 8 (1): 11-18

Fjørtoft I, 2000. Motor fitness in pre-primary school children: The eurofit motor fitness test explored on 5-7-year-old children. Pediatric Exercise Science. 12 (4): 424- 436

Franjoine MR, Gunther JS, Taylor MJ, 2003. Pediatric balance scale: A modified version of The Berg Balance Scale for the school-age child with mild to moderate motor impairment. Pediatric Physical Therapy. 15 (2): 114-128

Gallahue DL, Ozmun JC, Goodway J, 2006. Understanding Motor Development: Infants, Children, Adolescents, Adults. McGraw-Hill: Boston

Geyser E, 2009. The Agreement Found Between the Sensory Profiles of Children 3-10 Years and Their Biological Parents. PhD Thesis, University of Witwatersrand

Gür H, 2018. An examination on the effects of balance training with biodex balance system of multiple sclerosis patients on the balance, walking and functional parameters. Thesis in Medicine University of Kirıkkale

Gündoğdu Z, Seytepe Ö, Pelit BM, Doğru H, Güner B, Arıkız E, Kaya E, 2016. Okul öncesi çocuklarda medya kullanımı. Kocaeli Üniversitesi Sağlık Bilimleri Dergisi. 2 (2): 610

Gürbüz S, Şahin F, 2017. Sosyal Bilimlerde Araştırma Yöntemleri. 4. basım. Seçkin Yayıncllik, Ankara

Hazar F, Taşmektepligil Y, 2008. Puberte öncesi dönemde denge ve esnekliğin çeviklik üzerine etkilerinin incelenmesi. Spormetre Beden Eğitimi ve Spor Bilimleri Dergisi. 6 (1): 9-12

Henriksson NG, Johansson G, Olsson LG, Östlund H, 1967. Electric analysis of The Romberg Test. Acta Oto-Laryngologica, 63 (224): 272-279

Horvat M, Franklin C, 2001. The effects of the environment on physical activity patterns of children with mental retardation. Res Q for Exerc Sport. 72 (2): 189-195

Huri M, Gündüz F, 2016. Üstün Yetenekli Çocuklarda Duyu Temelli Ergoterapi Grup Müdahalesinin Duyu Modülasyonu, Postural Praksis ve Bilateral Motor Koordinasyon Becerileri Üzerindeki Etkisinin İncelenmesi: Pilot Çalışma

Jorquera-Cabrera S, Romero-Ayuso D, Rodriguez-Gil G, Triviño-Juárez JM, 2017 Assessment of sensory processing characteristics in children between 3 and 11 years old: A systematic review. Frontiers in Pediatrics. 5: 57

Kara ÖK, Mutlu A, Günel MK, Karahan S, Livanelioglu A, 2011. Serebral Palsi'li çocuklarda kaba motor fonksiyon ve denge parametrelerinin karşılaştırılması. 2. Pediatrik Rehabilitasyon Kongresi Fizyoterapi Rehabilitasyon. 22 (3): 18

Karacan Ç, Kaba Z, Yenigün Ö, Aydın M, Bayazıt B, 2003. Kaynaştırma grubu ile eğitilebilir zihinsel engelli grubun ritm ve dans çalışmaları yoluyla beceri 
düzeylerinde meydana gelen değişimlerin incelenmesi. İstanbul Üniversitesi Spor Bilimleri Dergisi. 11 (3): 132-136

Kayıhan H, Akel BS, Salar S, Huri M, Karahan S, Turker D, Korkem D, 2015. development of a Turkish version of the sensory profile: Translation, cross-cultural adaptation, and psychometric validation. Perceptual and Motor Skills. 120 (3): 971-986

Kosma M, Wood TM, Rintala P, Acock AC, 2004. A comparison of the effects of healthrelated fitness and motor ability on adaptive behavior among adults with intellectual disabilities. Journal of Human Movement Studies. 47 (4): 303-326

Kubilay NS, 2008. Effect of balance training and posture exercises on functional level in individuals with mental retardation. Master Thesis, University of Dokuz Eylül

Mikołajczyk E, Jankowicz-Szymańska A, 2014. The effect of unstable-surface functional exercises on static balance in adolescents with intellectual disability-a preliminary report. Medical Studies/Studia Medyczne. 30 (1): 1-5

Molnar G. 1978, analysis of motor disorder in retarded infants and young children. American Journal of Mental Deficiency: 83: 213-221

Odabaş C, 2016. Examine the effects on individual skills of children with autism in regular sports training. Master Thesis, University of Bartın

Özer D, Aral N, Özer K, Güvenç, A, 1999. Eğitilebilir zihinsel engelli çocukların fiziksel özelliklerinin normal gelişim gösteren yaşıtları ile karşılaştırılarak incelenmesi. CBÜ Beden Eğitimi ve Spor Bilimleri Dergisi. 3 (4): 1-17

Özer DS, 2013. Engelliler İçin Beden Eğitimi ve Spor. 4. basım, Nobel Yayın Dağıtım: Ankara

Öztürk MO, 1995. Ruh Sağlığı ve Bozuklukları, 6. basım, Hekimler Yayın Birliği: Ankara Rarick GL, Dobbins DA, 1972. Basic component in the motor performance of educable mentally retarded children: Implications for curriculum development. U.S Office of Education. Washington

Rodriguez FA, Valenzuela A, Gusi N, Nacher S, Gallardo I, 1998. Evaluation of the healthrelated fitness in adults (II): Reliability, feasibility and reference norms by means of the afisalinefc. Apunts Educacion Fisicay Deportes. 54: 54-65

Schaaf RC, Miller LJ, 2005. Occupational therapy using a sensory integrative approach for children with developmental disabilities. Mental Retardation and Developmental Disabilities Research Reviews. 11 (2): 143-148

Selçuk R, 2018. Özel öğrenme güçlüğü olan çocuklarda çift görev odaklı denge egzersizlerinin denge ve öğrenme üzerine etkisi. Journal of Exercise Therapy and Rehabilitation. 5 (2): 65-73

Siedentop D, Mond C, Toggort A, 1986. Students With Special Needs. Physical Education Teaching and Curriculum Strategies for Grades 5-12. California: May Field Publishing Company Mountain View

Sinclaire E, Forness S, 1983. Classification: Educational issues. (Ed: L. Matson) Handbook of Mantel Retardation. Pergaman Press: New York

Smail KM, Horvat M, 2001. Effects of balance training on individuals with mental retardation. Percept Motor Skills; 79 (2): 643-9 
Sterkowicz S, Lech G, Ambroży T, 2012. Coordination motor abilities of judo contestants at different age. Journal of Combat Sports and Martial Arts. 1 (2): 5-10

Sundstrup E, Jakobsen MD, Andersen JL, Randers MB, Petersen J, Suetta C, Krustrup P, 2010. Muscle function and postural balance in lifelong trained male footballers compared with sedentary elderly men and youngsters. Scandinavian Journal of Medicine \& Science in Sports. 20: 90-97

Tomchek SD, Dunn W, 2007. Sensory processing in children with and without autism: A comparative study using The Short Sensory Profile. The American Journal of Occupational Therapy. 61 (2): 190-200

Ulla L, Pauli R, Antero M, 2007. physical performance of individuals with intellectual disability: A 30 years follow up. Adapted Physical Activity Quarterly. 24 (2); 125143

Vakulenko YV, 2020. Sense and self-regulation checklist: adaptation on Ukrainian sample of typical children and children with autism spectrum disorder, doi: https://doi.org/10.29013/AJH-20-5.6-11-18

Vuijk PJ, Hartman E, Scherder E, Visscher C, 2010. Motor performance of children with mild intellectual disability and borderline intellectual functioning. Journal of Intellectual Disability Research. 54 (11): 955-965

Wilson CH, Brice C, Carter EI, Fleming JC, Hay DD, Hicks JD, Weaver J, 2011. Familiar technology promotes academic success for students with exceptional learning needs. https://eric.ed.gov/?id=ED530541

Winnick J P, Porretta DL, 2017. Mental Retardation. Adapted Physical Education and Sport. 6. edition. Human Kinetics: USA

World Health Organization. Intellectual Disability A Manual for CBR Workers. New Delhi: 2007; s: 15. www.searo.who.int. Accessed 14 November 2018

Yağcı N, Cavlak U, Şahin G, 2004. İşitme engellilerde denge yeteneğinin incelenmesi üzerine bir çalışma. KBB-Forum; 3(2): 45-50

Zeng N, Ayyub M, Sun H, Wen X, Xiang P, Gao Z, 2017. Effects of Physical Activity on Motor Skills and Cognitive Development in Early Childhood: A Systematic Review, BioMed Research International, Volume 2017, Article ID 2760716, https://doi.org/10.1155/2017/2760716 
Faruk Salih Şeker, Hüseyin Çamlıyer

THE EFFECT OF MOVEMENT TRAINING ON BALANCE

SKILLS IN CHILDREN WITH INTELLECTUAL DISABILITY

Creative Commons licensing terms

Authors will retain the copyright of their published articles agreeing that a Creative Commons Attribution 4.0 International License (CC BY 4.0) terms will be applied to their work. Under the terms of this license, no permission is required from the author(s) or publisher for members of the community to copy, distribute, transmit or adapt the article content, providing a proper, prominent and unambiguous attribution to the authors in a manner that makes clear that the materials are being reused under permission of a Creative Commons License. Views, opinions and conclusions expressed in this research article are views, opinions and conclusions of the author(s). Open Access Publishing Group and European Journal of Special Education Research shall not be responsible or answerable for any loss, damage or liability caused in relation to/arising out of conflict of interests, copyright violations and inappropriate or inaccurate use of any kind content related or integrated on the research work. All the published works are meeting the Open Access Publishing requirements and can be freely accessed, shared, modified, distributed and used in educational, commercial and non-commercial purposes under a Creative Commons Attribution 4.0 International License (CC BY 4.0). 